\title{
BERNARD LONERGAN AND ALBERTO GUERREIRO RAMOS: DIALOGUES BETWEEN THE EXISTENTIAL SUBJECT AND THE PARENTHETICAL MAN
}

\author{
Bernard Lonergan e Alberto Guerreiro Ramos: diálogos entre \\ 0 sujeito existencial e 0 homem parentético
}

\author{
Laís Silveira Santos* \\ Mauricio C. Serafim** \\ Daniel Moraes Pinheiro ${ }^{\star \star *}$
}

\section{ABSTRACT}

Bernard Lonergan has addressed, among other topics, the issue of human and ethical action, considering the possibility of a path of authenticity and moral achievement that occurs in a specific type of subject, whom he has called the existential subject. Based on this concept, we considered the possibility of a dialogue with Alberto Guerreiro Ramos, who has created the concept of parenthetical man, defined as a being that is rational par excellence, in his substantive dimension. The conception of this model of man goes in an opposite direction of the management theories based on instrumental rationality. Although Lonergan has not explicitly created a substantive theory, his concept of ethics and human good highlights aspects that relate to the substantive rationality. Thus, this theoretical essay aims to identify the possible connection between the parenthetical man and the existential subject, based on the perspective of human action and ethics. We identified that the authors have a similar comprehension of the world and of human relations, especially regarding the critical consciousness of the parenthetical man and the awareness of responsibility of the existential subject.

Keywords: Bernard Lonergan. Guerreiro Ramos; Ethic. Existential subject. Parenthetical man.

\section{RESUMO}

Bernard Lonergan abordou, entre outros temas, a questão da ação humana e ética, considerando possível um caminho de autenticidade e realização moral que se dá num tipo de sujeito, que denominou de sujeito existencial. A partir dessa concepção, vimos uma possibilidade de diálogo com Alberto Guerreiro Ramos, que criou o conceito de homem parentético, definido como um ser racional por excelência, em sua dimensão substantiva. A concepção desse modelo de homem vai de encontro à visão das teorias administrativas que se baseiam na racionalidade instrumental. Embora Lonergan não tenha criado, explicitamente, uma teoria substantiva, sua concepção de ética e bem humano destaca aspectos que remetem à razão substantiva. Assim, este ensaio teórico objetivou identificar as possibilidades de aproximação entre o homem parentético e o sujeito existencial, a partir das perspectivas da ação humana e ética. Identificamos que os autores possuem uma compreensão semeIhante de mundo e dos relacionamentos humanos, destacando-se a questão da consciência crítica do homem parentético e a consciência da responsabilidade do sujeito existencial.

Palavras-chave: Bernard Lonergan. Guerreiro Ramos. Ética. Sujeito existencial. Homem parentético.

* PhD student in Administration at the Universidade do Estado de Santa Catarina (Esag/Udesc). Master of Administration at the Universidade Federal de Santa Catarina (UFSC). Researcher at the Núcleo de Pesquisa e Extensão em Inovações Sociais na Esfera Pública (Nisp/Udesc). Email: lais.ssantos@yahoo.com.br. ORCID: 0000-0002-4737-5470

** Professor of the Department of Public Administration and of the Postgraduate Program in Administration at the Universidade do Estado de Santa Catarina (Esag/Udesc). Ph.D. in Administration from Fundação Getúlio Vargas (Eaesp/FGV). Researcher at Núcleo de Pesquisa e Extensão em Inovações Sociais na Esfera Pública (Nisp/ Udesc). Email: serafim.esag@gmail.com. ORCID: 0000-0002-4852-5119

*** Professor of the Department of Public Administration of the Universidade do Estado de Santa Catarina (Esag/ Udesc). Ph.D. in Administration from Universidade Federal de Santa Catarina (UFSC). Researcher at Núcleo de Pesquisa e Extensão em Inovações Sociais na Esfera Pública (Nisp/Udesc) and at Núcleo Organizações, Racionalidade e Desenvolvimento (ORD/UFSC). Email: daniel.m.pinheiro@gmail.com. ORCID: 0000-0002-7731-8178 


\section{INTRODUCTION}

$\mathrm{T}$ he Canadian philosopher, theologian and economist Bernard Lonergan (1904-1983), although little known in Brazil ${ }^{1}$, is considered one of the most important philosophers of the twentieth century (HENRIQUES, 2010). His life was dedicated to the study of ethics, economics, epistemology and theology, focusing on authors of the theory of knowledge, on classical works of Greek philosophers such as Socrates, Plato and Aristotle, and medieval thinkers such as St. Augustine and Thomas Aquinas. In addition, Lonergan has accumulated great knowledge about modern and contemporary philosophy.

When coming across Lonergan's work and studying his research lines, especially his theory of knowledge - which deals with human action and its ethics, among other themes - we observed that, considering the importance and depth of his work, a dialogue could be established with the work of the Brazilian author Alberto Guerreiro Ramos. Guerreiro Ramos (1915-1982), still not duly recognized and valued in Brazil, is a sociologist who devoted part of his studies to the understanding of reason and of a science that properly underlies and understands human actions and social systems planning. During the time of studying and writing for his last work A Nova Ciência das Organizações (The New Science of Organizations), Guerreiro Ramos had contact with Lonergan's work and used it in his book, in the second chapter, as one of the references to elaborate a critique of the contemporary model of social science, in view of its substantive theory of associated human life.

Both authors, perhaps with distinct purposes, adopt ontological, epistemological, anthropological, and theological bases that are close to the same worldview ${ }^{2}$, using similar - and some of them shared - foundations. An example is the use of classical metaphysics as a basis for their work. This led us to conduct a study in order to connect both authors theoretically. Given the complexity, depth, and intellectual greatness of them both, this endeavor focuses on the points where they seem to converge: the debate on human action and its ethical aspects from a substantive point of view. In this context, Guerreiro Ramos created the concept of parenthetical man, defined as a rational being par excellence, and reason is understood in its substantive and noetic dimension (GUERREIRO RAMOS, 1972, 2001; AZEVEDO; ALBERNAZ, 2006).

The idea of the parenthetical man goes against the view of administrative theories that are based on instrumental rationality and that ignore psychological implications and human nature. Guerreiro Ramos understood that the administrative theory could no longer legitimize the functional rationality of the organization, and thus believed that the parenthetical man model could provide the theory the "conceptual sophistication to confront issues and problems involving tensions between noetic and functional rationality" (GUERREIRO RAMOS, 1972, p. 243). In this way, the author sought a new science of organizations conceived on the basis of substantive reason.

1. This is explained throughout the essay.

2. This essay adopts the following definition of worldview: a fundamental orientation that can be expressed as a story or in a set of assumptions that one holds (consciously or unconsciously) about the basic constitution of reality. This orientation offers the foundation on which we live, act and exist (SIRE, 2012). 
Although Lonergan did not explicitly create a substantive theory as did Guerreiro Ramos, his conception of ethics and human good is close to an approach that highlights aspects that seem to refer to substantive reason based on transcendental notions of being and value (COVARRUBIAS, 2013). For Lonergan, by placing value judgments in the decision-making process, a path of authenticity and moral achievement is possible in a type of subject that he called an 'existential' or 'responsible' subject (NEIRA, 2008). The subject knows what acting means and does so consciously (WEBB, 2013, p. 114).

Thus, based on Guerreiro Ramos's parenthetical man as a possibility for advancement in the theory of administration, and on the recognition of Lonergan's approach as complementary to Ramos contributions, this essay aims to identify the possibilities of a theoretical dialogue between the parenthetical man and the existential subject, departing from the perspectives of human action and ethics. We argue that it is in the complementarity of the categories (rationality, awareness level and conduct) that the model of parenthetical man contributes, according to Guerreiro Ramos (1972, p. 243), to the "[...] conceptual sophistication to confront issues and problems involving tensions between noetic and functional rationality". In addition, we advocate that there are elements in Lonergan's concept of existential subject that refer to substantive reason and that place value judgments in the decision-making process, collaborating towards the understanding of individuals in organizations that are no longer conditioned to behave in an operational and reactive way, but who seek to exercise their critical capacity and ethical reflection.

\section{THE MODEL OF PARENTHETICAL MAN BY GUERREIRO RAMOS}

Alberto Guerreiro Ramos inspired many works in the field of organizational studies; works that aim both to understand and to criticize or pose questions about his academic production. As Begazo and Agurto (2003) point out, there are scholars who consider him to be merely a theoretical author, distant from reality, and there are several others who recognize Guerreiro Ramos as an innovator, mainly for starting to rethink the role of $\operatorname{man}^{3}$ in the organizational world.

The work of Guerreiro Ramos is notably marked by a concern with the condition of contemporary man. For Azevedo and Albernaz (2006), it is an anthropocentric sociology, characterized by an "integral humanism", in which intellectual work denotes the centrality of understanding a human being in all his dimensions. It is possible to observe the conflicts between man and social systems, the need for an expanded understanding of human reason, and numerous traces of a sociology that seeks to consider the essence of the individual.

This "anthropo-theory", or the theory of models of man (VAZ, 2004, p. 4), by Guerreiro Ramos (AZEVEDO; ALBERNAZ, 2006, p. 5) is present in different moments of his life, his academic and political career, as well as in his Christian-Catholic education. Guerreiro Ramos reflected on the human condition based on the thoughts of Christian intellectuals, on

3. We are aware that, in this case, the word "man" is outdated and is not in line with the current norms of referring to gender. However, we decided to keep it in order to be coherent with the terms used by Ramos.

4. This is the term originally used by the philosopher and theologian Jacques Maritain (1945), who is one of the influences of Alberto Guerreiro Ramos. 
discussions of social and racial problems (in which he strongly identified with black culture), on critical thinking as an activist, and on the human condition in market-centered society, in which social science, and more specifically, organizational theory and administrative theory (SOARES, 1995; AZEVEDO; ALBERNAZ, 2006) are inserted. The ethical commitment to social life (ARTEAGA, 2009), the engagement (BOAVA; MACEDO; ICHIKAWA, 2010), is clear in his work, in his perception of man, critical and conscious of reality. In his work, we can also highlight a search for an explanation of the national problems in the light of a national base, taking into account the local social and historical reality (DE OLIVEIRA, 2012; FLORES, 2015).

Over the years, Guerreiro Ramos is blunt in denouncing that the human condition - in its public/political or private dimension - is primarily marked by a functional rationality that guides human life and actions. This is a characteristic that stood out at the time and is currently in the agenda in Administration studies.

His work resonates in the field of Administration, mainly when it comes to issues such as autonomy and the man's search of sense when facing the problems of contemporary society. Discussing elements of reason is part of his concern, and this is crucial to understand his work and to make it possible to discuss man and his social role.

Guerreiro Ramos highlights in his studies - inspiring several subsequent works, such as Serva et al. (2015) - the substantive (or noetic) reason category. When explaining substantive rationality, he will emphasize the centrality of ethical judgment. This is precisely the reason inspiring researchers in the field of Administration. In their work, they seek a rationality that is opposed to that one commonly observed in traditional organizations (functional rationality), or they highlight the role of man in society and in the world of organizations that, "[...] because of substantive rationality [the man] is more aware of his role in the world, opening a discussion about the true logic of social action when this individual recognizes that the predominant system reduces his analytical capacity" (MUZZIO, 2014, p. 710).

Considering the conceptions of rationality, Guerreiro Ramos describes three models of man (anthropo-theory), as presented in his article Modelos de Homem e Teoria Administrativa (Models of Man and Administrative Theory). Guerreiro Ramos (1972, 2001) recognizes the existence of the operative man, the reactive man and, based on the state of the art and the theory of Administration, proposes a new model: the parenthetical man.

Guerreiro Ramos $(1972,2001)$ says that the operational man is the equivalent to the homo economicus of the classical economics. He is considered a resource within the organizational context; a resource that must be maximized in terms of the physical product. In this sense, the worker is seen as a passive being, programmable and adjustable to the imperatives of production maximization. Their motivation is calculated and driven by material and economic rewards and their personal freedom is not considered when it comes to the organizational model.

Guerreiro Ramos $(1972,2001)$ refers to the "reactive man" as the model developed by the school of human relations. He is the man for whom Administration aims to reinforce the behaviors of the specific organizational rationality. Ramos warns that despite the concern of the humanists with the workers, the objectives did not change and this 
model of man still reflects a worker adjusted to the context of work and not to his individual growth or self-actualization. Such a situation gives rise to the "organizational man" and to the integration between individual and organization to the expense of individual awareness.

For Guerreiro Ramos $(1972,2001)$, this integration creates a problem, since it is not easy to separate what would correspond to the human being's individual-private space and the organizational space. Consequently, in the integration between individual and organization, the "double character of rationality" is also ignored. Guerreiro Ramos then draws attention to the substantive or noetic dimension, which does not correspond to the standards of the administrative behavior, as outlined in the organizational man. In his words, "a human behavior occurring under the aegis of noetic rationality only may be administrative by accident, not by necessity" (GUERREIRO RAMOS, 1972, p. 243). The individuals, when placed in the organizational context, when feeling unable to make ethical judgments - such as judging the organization, its leaders and behaviors - can find themselves challenged with moral dilemmas arising from the tension between the ethics of conviction and the ethics of responsibility (SANTOS, 2012).

In his book Administração e Contexto Brasileiro (Administration and the Brazilian Context), Guerreiro Ramos (1983) uses a chapter to explore the theme 'ethical tensions in organizations'. The author uses the terms ethics of conviction and ethics of responsibility, in which the first - also called the ethics of absolute value - is implicit in actions concerning values, while the second is contained in the actions related to purposes. Thus, these ethics are closely related to the rationality that guides the action of individuals; however, not necessarily in an antagonistic way. In his view, "one can admit congruence between the two ethics, to the extent that the qualifications and the nature of the work are consistent with the values of the individual. Consequently, except in extraordinary cases, no individual organizes their behavior under one of the two ethics specifically" (GUERREIRO RAMOS, 1983, p. 43).

When the human being finds the substantive legitimacy of their action, without the imposition of rules and following substantive reason, they act under the imperative of the ethics of conviction. When there is the imposition of rules and the legitimacy of acting is an attribute previously defined by the group to which they belong, the human being acts or behaves under the imperative of the ethics of responsibility, linked to instrumental reason (Table 1). In short, we have:

Table 1 - Synthesis of the main Weberian categories

\begin{tabular}{cccc}
\hline Social action & Criteria & Process & Ethic \\
\hline $\begin{array}{c}\text { Rational action referred } \\
\text { to the ends }\end{array}$ & Functional rationality & Adaptation means/ends & Ethics of responsibility \\
\hline $\begin{array}{c}\text { Rational action referred } \\
\text { to values }\end{array}$ & Substantive rationality & Valuing orientation & $\begin{array}{c}\text { Ethics of conviction or of } \\
\text { absolute value }\end{array}$ \\
\hline
\end{tabular}

Source: Serafim (2001).

Guerreiro Ramos (1989), when demonstrating the loss of the capacity of the individual's reason to normalize their own conduct, discusses what he calls the behavioral syndrome, characterized by the loss of capacity and the difficulty of performing actions 
guided by ethics. In this sense, the author makes a distinction between behavior and action, as in Table 2 below:

Table 2 - Distinction between behavior and action

\begin{tabular}{ll}
\hline \multicolumn{1}{c}{ CONDUCT } \\
\hline \multicolumn{1}{c}{ Behavior } & \multicolumn{1}{c}{ Action } \\
\hline $\begin{array}{l}\text { Form of conduct based on functional } \\
\text { rationality or in utilitarian estimation } \\
\text { of consequences (common to human } \\
\text { being and animals) }\end{array}$ & $\begin{array}{l}\text { Typical of the agent that makes decision } \\
\text { because they are aware of the intrinsic } \\
\text { aim }\end{array}$ \\
\hline $\begin{array}{l}\text { The most important category: conve- } \\
\text { nience }\end{array}$ & $\begin{array}{l}\text { Most important category: substantive } \\
\text { pattern of conduct }\end{array}$ \\
\hline $\begin{array}{l}\text { There is no generally accepted ethical } \\
\text { content }\end{array}$ & $\begin{array}{l}\text { It is an ethical form of conduct (that can } \\
\text { be adopted universally) }\end{array}$ \\
\hline $\begin{array}{l}\text { Dictated by external imperatives } \\
\text { (mechanomorphic behavior) }\end{array}$ & $\begin{array}{l}\text { It recognizes the intrinsic value of the } \\
\text { aims }\end{array}$ \\
\hline $\begin{array}{l}\text { It can be considered functional or } \\
\text { effective and it is completely included } \\
\text { in a world based on efficient causes }\end{array}$ & $\begin{array}{l}\text { The human being acts, makes decisions } \\
\text { and chooses why final causes (and not } \\
\text { only efficient causes) influence the world } \\
\text { in general }\end{array}$ \\
\hline
\end{tabular}

Source: Serafim (2001).

In this line, the behavioral syndrome is a misrepresentation of the substantive notion of human conduct, becoming the basic characteristic of contemporary societies, which are the "culmination of a historical experience, now three centuries old, that tries to create a type, never observed before, of a human life associated with, ordered and sanctioned by the market self-regulating processes" (GUERREIRO RAMOS, 1989, p. 52). The incompatibility between the values of an individual - which are complex and not limited to purely economic reasons - and the values of the organization, requires from subjects what Guerreiro Ramos (1983) and Mannheim (1962) call the "self-rationalization" of conduct, which can be perceived in the characteristics of the parenthetical man. This type of man, although still a participant of the organization, has the psychological capacity to resist the harm organizations may cause to the human's behavior (AZEVEDO; ALBERNAZ, 2006). The consciousness of this attitude would affect human awareness and conduct, allowing humanity a new phase in its process of associated human life. According to Guerreiro Ramos (1996, p. 48):

Consciousness comes when the human being or a social group reflects on these social and external conditions and guide themselves in face of them as a subject. It differs from naïve awareness, which is the pure object of external determination. The emergence of consciousness in a human being or social group necessarily signals the subject's or group's better comprehension of the conditioning factors. Compared to naïve awareness, consciousness is a radically distinct way of apprehending the facts, resulting not only in human conduct that is more alert and cautious, but also in an attitude of control over oneself and external control. 
Guerreiro Ramos gets inspiration from the noetic rationality of Eric Voegelin (CAPELARI et al., 2014), the classical Greek philosophers (Plato and Aristotle), the personalist philosophy (especially Jacques Maritain) and the phenomenology of Husserl and Heidegger, and creates a model of man that is more comprehensive than that responding to a high degree of functional rationality. Therefore, the parenthetical man emerges with "new priorities" (BULGACOV; CASTIGLIA, 2003), seeking to overcome the organizational dilemmas in an enlightened, engaged and critical way, capable of acting and reflecting. The parenthetical man is able to perceive and identify the conditions placed by personal and social factors, acting out of the reflections about his own values, examining the context, but also observing his own needs, with self-control and the ability to give meaning to their work (MOZZATO; GRZYBOVSKI, 2013; FLORES, 2015; BONDARIK; PILATTI, 2007; DURANTE; TEIXEIRA, 2008; SANTOS; SANTOS; BRAGA, 2015).

Thus, "the parenthetical man is ethically committed to values conducive to the primacy of reason (in the noetic sense) in social and individual life" (GUERREIRO RAMOS, 1972, p. 244). Additionally, he has the necessary autonomy and consciousness developed from value premises that do not let him be psychologically framed as happens in the reactive and operational models. The parenthetical man's ability to "put the environment between parentheses" enables him to examine and assess the situations as a spectator, in the first moment, in order to then become a subject. It is the result of a self-determination attitude preceded by an understanding of the environmental and social conditions that affect him. In other words, the parenthetical man learned certain cultural skills that enable him to "[...] transcend, as far as possible, the circumstantial constraints that conspire against his free and autonomous expression" (GUERREIRO RAMOS, 1996, p. 11).

It is important to point out that this anthropo-theory is part of a project that Guerreiro Ramos carried out during his life. As he stresses in the preface of the second edition of his work A redução sociológica (Sociological Reduction) (GUERREIRO RAMOS, 1996), the "parenthetical attitude" is one of the three basic meanings of what he calls "reduction". This attitude was first outlined in the chapter Homem Organização e Homem Parentético (Organization Man and Parenthetical Man), in his book Mito e verdade da revolução brasileira (Myth and truth of the Brazilian revolution) (GUERREIRO RAMOS, 1963). The other two meanings are (a) reduction as a method of critical assimilation of the foreign sociological production, discussed in the book A redução sociológica (GUERREIRO RAMOS, 1996); (b) reduction as an overcoming of sociology in the current institutional and academic issues, a topic addressed in A nova ciência das organizações (The New Science of Organizations). (GUERREIRO RAMOS, 1989).

\section{ETHICS AND HUMAN ACTION FOR BERNARD LONERGAN: THE EXISTENTIAL SUBJECT}

The Canadian philosopher, theologian and economist Bernard Lonergan (1904 1983) is considered by some scholars as the most important philosopher of the twentieth century (HENRIQUES, 2010). During his education, Lonergan studied authors related to the theory of knowledge, classical texts of Greek philosophers such as Socrates, Plato and Aristotle, medieval thinkers such as St. Augustine and Thomas Aquinas, and accumulated great knowledge about modern and contemporary philosophy. In his professional career, he 
worked as professor, researcher and author of works related to ethics, epistemology, theology and economics.

His works and ideas inspired many admirers in several countries, such as Portugal, Spain, Canada, the United States and Colombia. Currently, there are more than ten research centers dedicated to his work, which produce research at master's and doctoral levels, and organize summits to discuss his thoughts and the impact of his contributions (HENRIQUES, 2010). However, there are few researchers in Brazil that know and cite Bernard Lonergan's production.

In a search conducted in the Scientific Periodicals Electronic Library (Spell) in March 2016, using the criterion "author cited", no work was found. During the same period, in the Portal of the Brazilian Digital Library of Theses and Dissertations - which gathers theses and dissertations published throughout the country, as well as those written by Brazilians abroad - the search for the keyword "Lonergan" in all fields returned only one Master's dissertation in Law, written in 1997. On the other hand, when searching for "Bernard Lonergan" in any part of the text, in the EBSCO Portal, 1,952 results were found - none of them produced by Brazilian authors. This information may indicate that Brazilian researchers are not familiar with the author, even though Lonergan is relatively relevant internationally. Therefore, it is important to briefly present Bernard Lonergan before approaching the focus of this essay, represented by his conception on ethics and human action, in which he develops the idea of the existential subject.

The book "Insight - A Study of Human Understanding", written between 1949 and 1953 and published in 1957, is considered the author's main work. Its reading is laborious, due to the influence of Latin in his writings, a language in which Lonergan was proficient. Lonergan called it a "self-appropriation project", because people are engaged in a process of self-knowledge, seeking answers in themselves and paying attention to their own knowledge. It is, therefore, an invitation to practice this process (HENRIQUES, 2010). Another work worth mentioning in his career is the book "Method in Theology" of 1964, in which he dedicates himself to a method of human understanding and envisions the ethical and religious scope that integrates the structure of the entire knowledge. Finally, another important work for this essay is "Collection - Collected Works of Bernard Lonergan", which is not well-known. It is important here because this work was used by Alberto Guerreiro Ramos when writing the second chapter of his work A Nova Ciência das Organizações (The New Science of Organizations). This collection presents shorter texts that cover Lonergan's work from 1943 to 1965 and discusses topics such as the proper foundation of metaphysics, the form of inference, the nature of love and marriage, and the role of the university in the modern world, among others.

As for Lonergan's epistemological position, he considered himself a critical realist because he sought to understand the conditions that allow knowledge and the man's role in the acquisition of conscious knowledge, and preoccupied with reality. For this, the author sought answers in the phenomenological analysis of human subjectivity, of the human subject throughout their conscious and intentional life (WALCZAK, 2008). Duffy (1996) argues that Lonergan's thinking does not represent a shift from critical philosophy to existentialism, but an integration of many of the concerns of existentialist writers within a critical realism. 
According to this position, Lonergan understands that knowledge is founded by a judgment that verifies how understanding explains or interprets data correctly. In the same sense, the moral conscience has a basis in the concrete knowledge of human good and, based on this conception, the author works on the topic of human and ethical action, where our main interest rests: the existential subject. However, according to Webb (2013), Lonergan did not undertake an analysis of the existential subject as thoroughly as he did about the insight. Nevertheless, his conception and understanding of the subject, human action and ethics are directly associated with the way in which the author understood the possibility of knowledge. Therefore, a brief description is needed, systematizing the configuration of the existential subject.

Lonergan's theory of knowledge is based on the desire to know: an unrestricted, impartial and unbiased desire to know (HENRIQUES, 2010). For the author, knowing is easy; the difficulty resides is to knowing the origin of the 'desire to know' and what happens in our minds when we have the knowledge. Knowledge comes from the self-appropriation by the subject, a thesis advocated in his work 'Insight', which he defines as a transcendental method, which goes beyond what is known and that underlies all types of knowledge (LONERGAN, 2010). The subject, in this sense and for the author, "is to be someone who performs intentional operations" (WEBB, 2013, p. 113). Through this line of argumentation of action, he builds a philosophy of consciousness to understand how we determine the characteristics of reality, that is, what we know by means of a true judgment.

For Lonergan (2010), knowledge occurs through insight, in a true noetic scope. Insight is not about methods, it is something that occurs when one understands and responds to a question arising from an experience, freeing us from the tension of inquiry. This would be the "insight", the capture of the concrete world through the senses, which can occur in all kinds of knowledge and sciences, as well as in common sense. According to the Institute of Noetic Sciences, the term "noetic" comes from the Greek nous, which means mind, inner wisdom, direct knowledge. As a discipline, it is a multidisciplinary field that brings scientific tools to study the full range of human experiences, i.e., subjective phenomena of consciousness, mind, spirit and life (INSTITUTE OF NOETIC SCIENCES, 2016).

The insights occur spontaneously, and one must ascertain whether they are correct or not. That is why Lonergan states that "knowing is identifying realities, through close experience, intelligent acquisition and reasonable affirmation" (HENRIQUES, 2010, p. 21). Thus, we have three basic ways of knowing, which form a threefold framework: a) experience provides separated pieces of information - experience data at the level of presentation/experiment; b) understanding captures a unity and explanations - level of intelligence/understanding; c) knowledge is only complete with the human act of judgment that captures a reality - level of reflection/judgment (WALCZAK, 2008). Within this possibility of knowledge, consciousness acts as the element that makes us connect things. With this argument, the author argued that it is only through the process of rational judgments and intelligent abstraction that we can identify realities.

In his philosophy of consciousness, Lonergan (2010, p. 317) understands consciousness as "an awareness immanent in cognitional acts" and argues that being conscious means performing the activity of thinking. He defines four levels of consciousness that are associated with the tasks of the proposed method of knowledge (DIMAS, 2014). In empirical 
consciousness, the individual feels, perceives, imagines, speaks, moves; the human lives, but does not care about its meaning. At the intellectual level, the individual understands, expresses the meaning, decides the assumptions and implications of the experience: the questions are "what", "why". At the level of rational consciousness, we realize the judgment about the true and the false; certainty or probability of a proposition. The last level of awareness is that of responsibility and freedom in which we assume our operations, evaluate their value, deliberate on the course of action, make a decision and act (DIMAS, 2014; LONERGAN, 2010; NEIRA, 2008).

From these levels of consciousness different types of subjects are associated. At the first level (empirical consciousness), the individual only experiences in an immediate way, existing only as an experiential or empirical subject. When they proceed to search for meaning and manage to get an insight in an intelligible form, they understand the fragments of a whole in a coherent and structured way, they become a subject who is more than just experiential: a subject of understanding (intellectual level). From the critical reflection on the adequacy of the understanding, besides being an empirical and intellectual subject, one becomes a rational subject (rational level). Finally, when the individual knows and understands the meaning of their action and does it consciously at the level of responsibility awareness, the existential subject arises (DIMAS, 2014; WEBB, 2013).

The existential subject is committed, but understanding and judgment do not occur in isolation. The subject's actions are contextualized for the pursuit of understanding and truth and, to a greater or lesser degree, is faithful to the ethical commitment (LONERGAN, 2012). From this understanding, Lonergan believes that the object of knowledge is the world as it is, in which the individual makes choices so that the possible becomes more likely. The individual operates with value judgments, deliberations and choices. In this sense and with this argument, Lonergan invites the subject to be an agent, a subject who chooses, and shifts his theory of insight - an exercise of intentional consciousness - to the existential exercise and to the practical life of the subject in society (HENRIQUES, 2010).

Thus, based on his network of understanding for the study of knowing, Lonergan presents the role of ethics when it comes to action and introduces the possibility of ethics as orientation for life, founded on the concept of goods (HENRIQUES, 2011). The insight typical of ethics, "which compels us and forces us to action, integrates good and goods, liberty and liberation" (HENRIQUES, 2010, p. 70). This 'good', for Lonergan, is based on Aristotle and refers to the reality desired and to our development as subjects who select "the world" in which we live. In this way, the intentional consciousness, presented in his theory of knowledge, is brought to the ethical discussion, but making the proper distinction and bringing it closer to the Aristotelian praxis, for which ethics is not practiced only through the acquisition of rules, but developing as moral beings and facing the domains of common sense (HENRIQUES, 2010). The ethical virtue in Aristotle is that which acts in practice, in the practical behavior and in the way of being in the search for the 'Good' (REALE; ANTISERE, 2005).

In the development of Lonergan's work there is a shift in the emphasis on "authenticity" and a distinct "notion of Good" (DUFFY, 1996). There is a refinement and a more adequate expression in later writings than that which is presented in the book Insight. In the book, the 'good' was the intelligent and reasonable. In Method in Theology, 'good' is related 
to questions for deliberation: is this worthwhile? Is this truly good or only seemingly good? There is an intentional response based on values and value judgments made by a virtuous or authentic person with a good conscience. Metaphorically, the intention of the 'good' is the "glue" of human consciousness (DUFFY, 1996).

In order to achieve the 'Good' we must seek the liberation of blockages and distortions, in a process that has advances and setbacks, located at the level of consciousness of the existential subject. Thus, when comparing the cognitive sequence of knowledge, "experience, insight and judgment", with ethics, there are "goods, liberty and liberation": "We desire and experience goods. We reflect and understand freedom. We try and perform acts of liberation" (HENRIQUES, 2010, p. 71). For this type of ethical insight, it is crucial to confront the realms of common sense that are interested in practical solutions (experiential subject), offering an inarticulate deduction and an incomplete set of insights. In order to confront these domains, one asks questions about what is worth the effort and what leads one to commitments and responsibilities (rational subject and existential subject), questions such as: what am I doing, is it worth it? Is it something really good and valuable or is it only good in appearance? (NEIRA, 2008). We are dealing, at this point, with the field of decision-making and value judgments.

This type of questions is linked to moral self-transcendence, i.e., what gives orientation to the personal life and to the life of the people around the individual, as well as to the achievement of what is considered by the agent as true, essential, and valuable. Self-transcendence is possible insofar as we are not locked within ourselves. We seek to go further, through and beyond, as in the questions mentioned above (NEIRA, 2008). This explanation is presented by Lonergan when he differentiates the terms "self-transcendence" and "self-regarding".

Self-transcendence as an operative process in terms of decisions and deliberations is associated with value judgments and the existential dimension, in which an individual or community has to decide what they want to do with their own destiny and life, that is, seeking human freedom. The processes of discernment are formed from the value judgments, and then it is possible to make decisions (NEIRA, 2008).

\section{THE POSSIBILITY OF COMPLEMENTARITY: LONERGAN'S CONTRIBUTIONS TO THE MODEL OF THE PARENTHETICAL MAN}

After this brief presentation of the foundations of Bernard Lonergan's work, it is possible to resume the discussion on the model of the parenthetical man developed by Guerreiro Ramos and look for elements that allow to establish connections between the visions of both authors and their models of man/subject. To start, Table 3 shows the main categories of analysis used to correlate, in a complementary way, the two types of man/ subject discussed in this essay. 
Table 3 - Synthesis with the main categories of analysis shared between the parenthetical man and the existential subject

\begin{tabular}{|c|c|c|}
\hline & Parenthetical man & Existential subject \\
\hline Concept & $\begin{array}{l}\text { A rational being par excellence, } \\
\text { who seeks to overcome dilemmas } \\
\text { and act in a clear, engaged, critical } \\
\text { way, and using the capacity of } \\
\text { acting and reflecting (MOZZATO; } \\
\text { GRZYBOVSKI, 2013; FLORES, } \\
\text { 2015; BONDARIK; PILATTI, 2007; } \\
\text { DURANTE; TEIXEIRA, 2008; } \\
\text { SANTOS; SANTOS; BRAGA, 2015). }\end{array}$ & $\begin{array}{l}\text { The subject is a "doer", able to } \\
\text { understand the meaning of their } \\
\text { actions and act in a consciously } \\
\text { responsible way, based on value } \\
\text { judgement, freedom and respon- } \\
\text { sibility (DIMAS, 2014; MORELLI; } \\
\text { MORELLI, 1997; WEBB, 2013). }\end{array}$ \\
\hline
\end{tabular}

\begin{tabular}{ll}
\hline The actions are based on their own reason and inherent attribute of the \\
individual as a creature of reason: noetic and substantive rationality, \\
of a true and self-evident nature, that allows the quest for freedom, \\
autonomy and self-actualization (DENNIS, 2009; GUERREIRO \\
RAMOS, 1972, 2001).
\end{tabular}

Source: Elaborated by the authors

Based on these "encounters of meaning" between the categories of analysis in Table 3 , we were able to sustain the assumption that both authors belong to a similar worldview, a similar way of understanding/seeing the world and human relations. From the analysis of the two authors' works, we believe that they have points in common that can correspond to a very close form of thinking about the human condition. The most important similarity is the question of the critical consciousness of the parenthetical man and Lonergan's notion of awareness of responsibility. Both reflect a deeply developed awareness of the value assumptions of the subject in action; a subject who seeks to free himself from "social naiveté", through the possibility of transcendence from the world as it is presented, and to act in such a way as to guide the subject's personal life and the life of the people around, based on what is considered to be essential and true, seeking freedom, autonomy and self-actualization (AZEVEDO; ALBERNAZ, 2006; GUERREIRO RAMOS, 1972, 2001; NEIRA, 2008;).

The similarity between Alberto Guerreiro Ramos and Bernard Lonergan is also observed in the fact that some authors are used by both of them, especially the philosopher Aristotle. In the work "The New Science of Organizations", Guerreiro Ramos (1989) emphasizes that for classical theorists, the human being is a political being (zoon politikon), endowed with reason and ethical imperatives, different from other animals. The author 
resorts to Aristotle to explain that, as a social being, man also calculates, as an economic agent, but in his private space (family); as a political being, man seeks to expand the good character of humankind (social interests).

Also departing from Aristotle and his metaphysical orientation that says that "all men by nature desire to know" (ARISTOTLE, 1984, Book I (A), 11), the philosopher and theologian Lonergan elaborates his theory of knowledge that assumes that "knowledge" and "desire" are two inseparable instances. Thus, what Lonergan called insight - that which is accomplished while the subject is understanding - is equivalent to "form" in Aristotle (OLIVEIRA, 2011).

In addition to Aristotle, it is worth mentioning the philosopher, historian and political scientist Eric Voegelin. Although there are points of contention between Lonergan and Voegelin, both are seen by Eugene Webb (2013) as "philosophers of consciousness". Guerreiro Ramos could also be included in this classification because of his reflections on the human condition. An aspect in common in the works of Guerreiro Ramos, Lonergan and Voegelin is the inclusion of philosophical conversations and authors of the classical and medieval period, bringing this content to offer bases to reflect on the human condition and the virtuous action in current times, as pointed out by Azevedo and Grave (2014) referring to Guerreiro Ramos. Also, according to Guerreiro Ramos (1989), Voegelin strongly criticized the neglect of the content of classical works such as Plato's and Aristotle's.

When thinking in terms of the possible complementarity or incorporation of Lonergan's legacy to the understanding of Guerreiro Ramos's works, especially when it comes to the notion of the 'parenthetical man', it is possible to observe in Lonergan a potential "method" to help, theoretically, in the construction proposed by Guerreiro Ramos. In other words, the way that knowledge and the levels of consciousness are defined by Lonergan are an invitation and a practical exercise for the person to pursue self-knowledge and answers from within (HENRIQUES, 2010). Guerreiro Ramos, when tracing the models of man and pointing to the parenthetical man as a "psychological capacity that would enable people to resist the harms organizations may cause to the human's behavior and psychology" (AZEVEDO; ALBERNAZ, 2006, p. 5), does not clearly or methodologically present, how this would happen. Guerreiro Ramos, in his book "The New Science of Organizations", which was published after his work on the models of man (1989, p. XVII), emphasizes that his work is the fruit of more than 30 years of research and reflection. However, the author also makes it clear that his study is only a start, for "it does not connect all that the new science consists of". It is a proposal of theoretical and operational study that was intended to be continued throughout his life.

Considering this, it makes sense to observe the contribution of Lonergan, who offers a method of analysis of human operations that allows better self-appropriation and orientation, in a way that our life can move in the direction of human authenticity and progress. We saw, therefore, a possibility of associating Lonergan's method as an alternative of action and reflection for the parenthetical man. Lonergan identifies a rational subject at their level of rational consciousness; however, at the level of responsible consciousness, he admits a responsible subject or an existential subject, who resembles the model of the parenthetical man because he is a subject who, more than just being someone who 'knows', becomes a 'doer': he deliberates, evaluates, chooses and acts. In this way, the subject's 
acting is free and responsible, but what gives meaning to action is the value judgment that guides the conduct. In the same way, the parenthetical man's conduct is guided by the lucid dimension of reason, that is, the one that "has a highly developed critical consciousness of value assumptions present in daily life; is able to understand the dictates of substantive reason, as opposed to the conditioning factors of behavior defined by external impositions" (JACOMETTI et al., 2013).

Lonergan's existential subject is the one who "knows what acting means and who does it consciously" (WEBB, 2013, p. 114). Therefore, the conduct, as well as the conduct of the parenthetical man, is not limited to simply "behaving", based on what is dictated by external imperatives and by convenience. On the contrary, the existential subject's conduct refers to "action", that of an agent who deliberates over things, because they are conscious of intrinsic purposes (SERAFIM, 2001). Both the parenthetical man and the existential subject are susceptible to existential tensions; however, they recognize, by value judgment associated with the predominance of a substantive rationality, the intrinsic value of the purposes.

The rationality of the parenthetical man is the reason itself, as defined in its substantive and noetic sense, as conceptualized by Karl Mannheim and Eric Voegelin, respectively (GUERREIRO RAMOS, 1972, 2001). Rationality, therefore, is seen understood as,

[...] the coordinated process of study, that seeks to identify patterns of order of the associated human life, patterns that are self-evident to the individual, regardless of the specific political and social structures [...]. These patterns do not arise from, or depend on, the opinion of the majority or the result of the interaction between divergent interests. They are true and self-evident [...]. (DENNIS, 2009, p. 204)

This same noetic sense of inner wisdom and direct knowledge is found in the concept of insight, as used by Lonergan (HENRIQUES, 2010; WEBB, 2013). Thus, both the existential subject and the parenthetical man have spontaneous insights - in a transcendental way - that enable the performance of intentional operations to determine the characteristics of reality through true judgement. The substantive or noetic rationality seems to appear in the same way, due to their self-evident nature and consciousness of the political and social conditioning, in order to overcome such conditioning.

\section{FINAL CONSIDERATIONS}

The density and depth of Bernard Lonergan's work requires an unusual effort to achieve a complete understanding, and the same is true for Alberto Guerreiro Ramos. Both authors present new elements, and new perspectives and understandings are obtained each time their work is studied. Nevertheless, it was possible, in this pioneer exploratory essay, to make a first attempt of bringing these authors together, by focusing on the two concepts they worked with, concepts that were presented in the objective established for this study.

Throughout this essay, we sought to show the two authors' views of man (existential and parenthetical), which are, at the same time, unique and complementary. Unique 
because they deal with an ethical dimension of human action that has designs and propositions of their own and very close to each other. Complementary because their similarities in designing the theoretical concepts allows us to envision the future operationalization of the categories proposed in this essay: rationality, level of consciousness and conduct.

It is precisely due to this complementarity of categories (rationality, level of consciousness and conduct) that we believe in the contribution of this essay to Guerreiro Ramos' observation that "the model of the parenthetical man may provide administrative theory with conceptual sophistication to confront issues and problems involving tensions between noetic and functional rationality" (GUERREIRO RAMOS, 1972, p. 243).

When we see, in the existential subject, elements that refer to substantive reason and that place value judgments in the decision-making process, there is, in our view, a contribution to the understanding of individuals who, within organizations, are no longer conditioned to behave in an operational and reactive way, but seek to exercise their critical capacity and ethical reflection. Researchers of organizational studies and managers in organizations, must learn to identify such dimension of the subject and not repress it, considering this dimension as a potential of creativity and expression in one of the dimensions that make up human existence.

There is a possibility that, when seeking to identify the possibilities of bringing the parenthetical man and the existential subject together - from the perspective of human and ethical action - we found more than an association between the two categories of condition of human action: we also discovered a theoretical-empirical possibility of understanding human action based on substantive reason and its transcendental nature.

We hope to have achieved the goal proposed in this essay and the next challenge is to insert Lonergan's legacy on the theory of knowledge, human action and ethics, in the context of theoretical-empirical studies in the field of organizational studies. Our reflections could contribute to further studies on substantive rationality and existential rationality, ethics of conviction and ethics of responsibility, as well as the existential tension between such ethics.

\section{REFERENCES}

ARISTÓTELES. Metafísica. Coleção Os Pensadores. São Paulo: Abril Cultura, 1984.

ARTEAGA, F. S. Teorías organizacionales desde una perspectiva latinoamericana. Psicología y organización, p. 161, 2009.

AZEVEDO, A.; GRAVE, P. S. Prolegômenos a toda a administrologia possível: Administração - $O$ que é isto? Organizações \& Sociedade, Salvador, v. 21, n. 71, p. 695-712, 2014.

AZEVEDO, A.; ALBERNAZ, R. A "antropologia" do Guerreiro: a história do conceito de homem parentético: em memória a Eliana Guerreiro Ramos (1949-2003). Cadernos EBAPE. BR, Rio de Janeiro, v. 4, n. 3, p. 01-19, 2006.

BEGAZO, J. D.; AGURTO, R. T. Del hombre autorrealizado al hombre modular. Revista de Investigación de la Facultad de Ciências Administrativas de Lima, Peru, v. 6, p. 55-66, 2003. 
BOAVA, D. L. T.; MACEDO, F. M. F.; ICHIKAWA, E. Y. Guerreiro Ramos e a Fenomenologia: redução, mundo e existencialismo. Organizações \& Sociedade, Salvador, v. 17, n. 52, p. 69-83, 2010.

BONDARIK, R.; PILATTI, L. A. Os modelos de homem de Alberto Guerreiro Ramos e os paradigmas produtivos do século XX. In: CONGRESSO INTERNACIONAL DE ADMINISTRAÇÃO, Ponta Grossa. Anais... Ponta Grossa, 2007.

BULGACOV, Y. L. M.; CASTIGLIA, F. Z. Dialogando com os princípios de uma abordagem substantiva da organização. Revista Psicologia Organizações e Trabalho, v. 3, n. 2, p. 11-34, 2003.

CAPELARI, M. G. et al. Alberto Guerreiro Ramos: Sociological Reduction Contributions to the Scientific Field of Public Administration in Brazil. RAM. Revista de Administração Mackenzie, v. 15, n. 6, p. 98-121, 2014.

COLET, D. S.; MOZZATO, A. R.; GRZYBOVSKY, D. Sentidos do Trabalho na Diversidade Geracional sob a Perspectiva Teórica das Racionalidades. In: Congresso Brasileiro de Estudos Organizacionais, 4, 2016. Anais eletrônicos... Porto Alegre, 2016. Available on: <https:// anaiscbeo.emnuvens.com.br/cbeo>. Accessed June 6, 2017.

COSTA, A. S. M. et al. Revisitando os estudos da Análise da Racionalidade nas Organizações no Brasil (2013 - 2016): Como se apresentaram as tendências nestes últimos anos? In: Colóquio Internacional de Epistemologia e Sociologia da Ciência da Administração, 6., 2017. Anais eletrônicos... Florianópolis: UFSC, 2017. Available on: <http://coloquioepistemologia.com.br/2017/anais-do-vi-coloquio>. Accessed June 6, 2017.

COVARRUBIAS, A. C. El juicio de valor y la hermenêutica. 2013. Available on: <http:// www. lonerganlat.org/wp-content/uploads/El-juicio-de-valor-y-la-hermen\%C3\%A9utica_Allan-Crhistian_ponencia.pdf>. Accessed 02 abr. 2016.

DE OLIVEIRA, J. S. Entrelaçando Estrutura Social e Produção de Conhecimento em Administração: Construindo Interfaces Analíticas a Partir da Sociologia de Guerreiro Ramos. Qualitas Revista Eletrônica, v. 13, n. 2, 2012.

DENNIS, C. M. Além da "raiz" e da "ramecência": por uma nova ciência para a formulação de políticas públicas. In: HEIDEMANN, F. G.; SALM, J. F.; GUIMARÃES, T. de A. Políticas públicas e desenvolvimento: bases epistemológicas e modelos de análise. Brasília, DF: Ed. UnB, 2009.

DIMAS, S. A Filosofia da Educação em Bernard Lonergan: 0 bem humano a que deve tender a educação contemporânea. In: HENRIQUES, M. C. Bernard Lonergan e a filosofia aplicada. Lisboa: Universidade Católica Editora, p. 66-84, 2014.

DUFFY, J. G. The Ethics of Lonergan's Existential Intellectualism. 1996. 276 f. Thesis (Doctor of Philosophy), Fordham University, New York, 1996.

DURANTE, D. G.; TEIXEIRA, E. B. Os limites e possibilidades de desenvolvimento humano nas teorias organizacionais. Desenvolvimento em Questão, v. 6, n. 11, p. 125-151, 2008.

FLORES, E. C. O conceito de "comunidade humana universal" na obra de Guerreiro Ramos.

Cadernos EBAPE. BR, v. 13, n. especial, p. 573-592, 2015. 
GUERREIRO RAMOS, A. A nova ciência das organizações: uma reconceituação da riqueza das nações. Rio de Janeiro: FGV, 1989.

. Modelos de homem e teoria administrativa. Série Monográfica: Caderno de Ciências Sociais Aplicadas, n. 3, Curitiba: PPAGEI/PUCPR, 2001. $16 f$.

. A redução sociológica. Rio de Janeiro: Editora UFRJ, 3 ed., 1996.

. Administração e contexto brasileiro: esboço de uma teoria geral da Administração. Rio de Janeiro: FGV, 2 ed., 1983.

. Models of Man and Administrative Theory. Public Administration Review, v. 32, n. 3, p. 241-6, May/June 1972.

. Mito e verdade da revolução brasileira. Rio de Janeiro: Zahar Editores, 1963.

HENRIQUES, M. C. Bernard Lonergan: uma filosofia para o século XXI. São Paulo: É Realizações, 2010.

. Bernard Lonergan e o Insight. São Paulo: É Realizações, 2011.

INSTITUTE OF NOETIC SCIENCES. What are the Noetic Sciences? Available on: <http:// noetic.org/about/what-are-noetic-sciences>. Accessed April 29, 2016.

JACOMETTI, M. et al. Fenonomia e isonomia no contexto da modernidade: possibilidades de um novo modelo social para as organizações. Revista Economia \& Gestão, v. 13, n. 32, p. 87-106, 2013.

LONERGAN, B. J. F. Collection. New York: Herder \& Herder, 1967.

Insight: Um estudo do conhecimento humano. São Paulo: É Realizações, 2010.

Método em Teologia. São Paulo: É Realizações, 2012.

MANNHEIM, K. O homem e a sociedade: estudos sobre a estrutura social moderna. Rio de Janeiro: Zahar, 1962.

MARITAIN, J. Humanismo integral. São Paulo: Cia. Editora Nacional, 1945.

MORELLI, M. D.; MORELLI, E. A. The Lonergan Reader. Toronto: University of Toronto Press, 1997.

MOZZATO, A. R.; GRZYBOVSKI, D. Abordagem Crítica nos Estudos Organizacionais: Concepção de indivíduo sob a perspectiva emancipatória. Cadernos EBAPE. BR, v. 11, n. 4, p. 520-542, 2013.

MUZZIO, H. A Condição Paradoxal da Administração de Recursos Humanos: Entre a Racionalidade Instrumental e a Racionalidade Substantiva. Cadernos EBAPE. BR, v. 12, n. 3, p. 706, 2014.

NEIRA F, G. El Dinamismo de los Juicios de Valor en la Autotrascendencia Moral. Theol. Xave., Bogotá, v. 58, n. 165, p. 201-224, 2008.

OLIVEIRA, E. T. O lugar da metafísica na filosofia da religião de Bernard Lonergan. PLURA, Revista de Estudos de Religião, v. 2, n. 2, p. 58-93, 2011.

REALE, G.; ANTISERI, D. História da Filosofia. São Paulo: Paulus, 2005. 
SANTOS, L. S. A tensão entre a racionalidade substantiva e a racionalidade instrumental na gestão pública: Novos caminhos de um campo de estudo. Florianópolis, 2012. Dissertação (Mestrado) - Universidade Federal de Santa Catarina, Programa de Pós-Graduação em Administração, 2012.

SANTOS, E. L.; SANTOS, R. S.; BRAGA, V. Administração do Desenvolvimento na perspectiva Guerreirista: conceitos, contribuições e implicações. Cadernos EBAPE. BR, v. 13, n. 3, p. 462, 2015.

SERAFIM, M. C. A Ética no espaço de produção: Contribuições da economia de comunhão. Florianópolis, 2001. Dissertação (Mestrado) - Universidade Federal de Santa Catarina, Programa de Pós-Graduação em Engenharia de Produção, 2001.

SERVA, M. et al. A análise da racionalidade nas organizações - um balanço do desenvolvimento de um campo de estudos no Brasil. Cadernos EBAPE. BR, Rio de Janeiro, v. 13, n. 3, p. 414-437, 2015.

SIRE, J. W. Dando nome aos elefantes: Cosmovisão como um conceito. Brasília: Editora Monergismo, 2012.

SOARES, L. A. Guerreiro Ramos: a trajetória de um pensamento. Revista de Administração Pública, 29: p. 33-50, 1995.

VAZ, H. C. de L. Antropologia filosófica. v. 1. São Paulo: Edições Loyola, 2004.

WALCZAK, M. Bernard Lonergan's Philosophy of Knowing. Revista de Filosofía, 45, 2008, p. 141-52.

WEBB, E. Filósofos da consciência: Polanyi, Lonergan, Voegelin, Ricoeur, Girard, Kierkegaard. São Paulo: É Realizações, 2013.

Submission date: 09/17/2016.

Approval date: 11/03/2017.

Creative Commons Atribuição 4.0 Internacional

Note: you can find this paper in Portuguese at http://www.revistaoes.ufba.br. 